\title{
Inquiry Into Which Area of the Life Extension Debate is Most Effective in Changing Attitudes Towards it Among 16 to 17 Year-Olds
}

\author{
Cassandra Temple ${ }^{1}$ and Mair Underwood ${ }^{\#}$ \\ ${ }^{1}$ ACS Cobham International School, Hersham, Cobham, UK \\ \#Advisor
}

\section{$\underline{\text { ABSTRACT }}$}

Existing research extension has yielded varying results about whether the public's attitudes towards life extension are positive or negative. Such differences could be accounted for by factors such as general attitudes towards developments in science and technology and exposure to fiction (such as books or movies) which generally portray life extension in an unfavorable light. This study revealed that, at least among 16 to 17 year-old High School Juniors, there was a correlation between a favorable orientation towards scientific and technological developments and positive attitudes towards life extension. Additionally, participants who had witnessed representation of life extension in fiction were less likely to hold positive attitudes towards it. The specification of the physical state in which people would live an extended lifespan in was also found to be significant in forming attitudes towards life extension. The main positive arguments about life extension were cited to be having more time, being able to be with loved ones longer, and it being beneficial towards society and humanity. However, the most significant negative arguments were that overpopulation would become a severe issue, outliving loved ones would be distressing, and abuse of power. In an attempt to change attitudes towards life extension from negative to positive, a 15-minute presentation about either the social and personal, ethical, or scientific aspect was generally ineffective in doing so. However, out of the favorable change that did occur, the presentation on the scientific feasibility of life extension was found to be the most effective.

\section{Introduction}

Among the most promising directions of biotechnological research is the prospect of extending human lifespan through methods such as gene therapy and tissue rejuvenation (Fahy et al). However, such a radical alteration of the human condition - especially with something as natural and universal as aging - has launched many debates about its ethicality, implications, and feasibility among not only the scientific community but also among the public. Existing research about attitudes towards life extension (LE) among the public covers virtually all ages ranging from university students to centenarians. However, there has not yet been a study that surveys the opinions of High Schoolers aged 16 to 17 years old. Additionally, most existing literature regarding attitudes towards LE has gathered information through one-stage survey inquiries about the public's (largely uninformed) perceptions of LE (Partridge et al, 2009) and antiaging technologies, which have been largely fueled by fiction that portrays these concepts in an unfavorable light (Underwood, 2014). Only Alvarez et al's LE study involved a two-stage survey methodology. Such structure was loosely emulated in this study. However, this study will not only survey attitudes but also attempt to change them.

\section{Research Statement}


The purpose of this mixed-method qualitative and quantitative survey-based study is to determine the extent to which attitudes towards life extension among 16 to 17 year-olds change after becoming more aware of various perspectives of the life extension debate: the scientific feasibility of it, supporting and opposing ethical arguments, and personal and social implications. This study aims to determine which area is most impactful on an individual's attitudes as well as what factors influence interest or opposition to LE technologies, thus providing life extension researchers with an indication as to which areas of concern or support to target when engaging in public discourse.

\section{Introduction into Life Extension}

Recent advances in the field of biotechnology and biogerontology such as CRISPR (a gene-editing tool that can eliminate and/or modify the genes that play a significant role in the aging process) have signified that humanity's dream of living longer is within sight. With all the ethical and social implications these new scientific advancements may have on people's lives, it is necessary for scientists and policymakers to listen to the public's concerns so that they can communicate with them more effectively and make mindful regulatory, financial, and research choices, which would minimize adverse consequences (Juengst, 2003) and allay hostile attitudes. Additionally, since the age group of this study is very likely to be impacted by LE technologies, it is important for scientists to be aware of this revolutionary concept so that they can make informed decisions about LE technologies when they become available to the general public.

LE is split into two types: strong and weak. H.R Moody defines weak LE as increasing the average human life expectancy by preventing premature death from diseases or injury without increasing the maximum life span which is currently around 120 years. Strong LE, however, would drastically increase life expectancy and push the maximum lifespan even further up. This study will focus on strong life extension since it is a much more polarizing issue, thus providing a better basis for stronger analysis of various perspectives and attitudes because of its potential to destabilize existing social, economical, and political institutions (Dragojlovic, 2013).

\section{Literature Review}

Generally, the extension of the human lifespan is not seen as a beneficial endeavor for humanity. For example, a 2005 study of adults in England and Wales established that the majority of participants (37\%) believed that gene therapies to slow the aging process should be banned with only $30 \%$ saying that they should be freely available (Calnan et al, 2005). Likewise, the minority (48\%) in a 2008 study favored life extension (Arber, Vandrevada, Daly, and Hampson, 2008). Even more notably, when asked if they think that therapeutic cloning should be accessible for a healthy individual who wants to live longer, an overwhelming 74\% of British adult participants in a 2007 study disagreed, contrasting with a majority supporting the use of therapeutic cloning for organ transplantation and treating Parkinson's (Shepherd et al, 2007). LE is thus established to be a much more ethically nuanced scientific development since it seeks not to cure those who are ill, but to better those who are already healthy, which could be perceived as "unnatural" (Partridge and Hall, 2007).

A 2011 study of elders aged 60 to 99 conducted by Calnan et al established that only one-fourth held positive attitudes towards LE and found that the desired life span was well within current measures (Cicirelli, 2011) and is corroborated by a 2007 study which revealed that people aged 20 to 90 on average wanted to live to age 85 (Lang, Baltes, and Wagner, 2007). However, these findings may be due to ambiguity about the conditions of an extended life (Partridge, Lucke et al, 2009). In fact, when Duncan conducted a New York Times survey in 2012 to ask for how long participants wanted to live, $60 \%$ of participants chose the lowest age (80 years) (Duncan, 2012) whereas when another study was conducted which specified continued health and youth, only $20 \%$ wanted to live until 80 and $42 \%$ wanted 
unlimited lifespans (Donner et al, 2016). This signifies a need for a study to eliminate such ambiguities and corroborate the notion that people would only be willing to live past the current maximum if they were to maintain their health.

Likewise to the New York Times survey, Donner et al in 2016 found that given perfect physical and mental health 797 out of 1000 participants wanted to live to 120 or older, and even more strikingly, over half of the 797 (40\% of all participants) wanted unlimited lifespans. Similarly, a 2018 YouGov survey also revealed that $60 \%$ of respondents explicitly desired LE. Additionally, Dragojlovic's 2013 study of the Canadian public concluded that 59\% of participants would be willing to live to 120 . It seems that, recently, attitudes towards LE have begun shifting in a favorable direction suggesting a need for a study to clarify whether that is truly the case or if the varying results are due to alternate phrasing of survey questions.

It is also interesting to note that Dragojlovic concluded in his study of the Canadian public that a major determinant of an individual's attitudes towards LE was their general orientation towards developments in science and technology. Yet his hypothesis is opposed by Calnan et al's survey demographic in which, despite having a majority of respondents being positive towards science, participants met possibilities of interfering with the natural aging process with opposition. Therefore, the results indicate there are other factors at play in determining an individual's perspective about life extension.

A possible reason why life extension is met with opposition and hostility may be due to a lack of knowledge and awareness about it. This may be corroborated by most participants in Partridge et al's 2011 study having limited knowledge about life extension with 54\% knowing nothing, 41\% knowing a little, and only 5\% knowing a lot. Additionally, only $35 \%$ of participants said they would be interested in using LE technologies. Similarly, a 2013 Pew Research Centre study found that $54 \%$ of people knew nothing of life extension, $38 \%$ knew a little, and only $7 \%$ knew a lot, which translated into $51 \%$ of respondents opposed life extension and only $41 \%$ were in favor. Since there is insufficient evidence to corroborate the hypothesis that a lack of knowledge justifies hostility towards LE, a study that explores this potential connection is needed.

Since a very small percentage of people know much about LE, others may base their ideas and perceptions of LE on fiction and popular media representations of 'immortality' which has very little validity in real-life applications. In a 2014 study, Underwood found that films centered around it often depicted LE as injurious and immoral and generally portrayed it in a very negative light. Such films act as cautionary tales for the possibilities that may arise if LE is widely introduced. Therefore, these films not only act as potential influences on the public's perception of LE but also reflect concerns that would need to be addressed in order to improve public opinion of LE technology research and development (Underwood, 2014).

\section{Ethical, Personal, and Social Concerns}

As stated previously, popular media such as films that involve the representation of LE reflect pertinent concerns among the public. Partridge et al's study found that despite $65.1 \%$ of participants supported life extension research, only 35.4\% would be willing to make personal use of that technology if it became available (Partridge et al, 2011). It is feasible that favorable perceptions towards science only pertain to research rather than "real-life" applications because of personal and societal ethical implications. Additionally, Partridge et al (in their 2009 study) found that a significant reason why people were against life extension was that they were inclined to think beyond their personal desires and consider how such technologies might impact others.

Most studies conducted discerning the most relevant ethical concerns about life extension technologies resulted in similar findings. In their 2009 study, Partridge et al found that the majority (58\%) of participants believed there to be ethical and moral issues associated with LE, and 80\% could identify at least one downside to LE pills being introduced. The most prominent ethical concern was found to be that it is "unnatural" and that it exerts too much control over natural processes. The next most significant concerns as indicated by various studies were that overpopulation would become an issue; social inequality would become more pronounced due to an unequal distribution of 
LE technologies; LE was incompatible with religious beliefs; resources would better be spent on more societally beneficial pursuits such as curing diseases and alleviating poverty. These findings are corroborated by numerous other studies, including another one of Partridge et al's study and by Alvarez et al's study. Both of these studies surfaced additional ethical concerns, such as LE being selfish, boredom in advanced ages, fear of outliving loved ones, unfairness to present and future generations, risk of societal stagnation, negative consequences on the environment, and that the job sector will change. Namely that jobs would become more scarce, hiring standards more rigid, and potential conflict between older and younger workers (Dragojlovic, 2013), (Alvarez et al, 2015).

\section{Present Research}

The goal of this study is to determine which area of debate surrounding LE (scientific feasibility, ethical concerns, and personal and societal concerns) is most effective at changing attitudes towards LE in a positive direction among sixteen to seventeen-year-old students. The study used three different video presentations and distributed them evenly to 6 classes, with one video shown per two classes. Using three different videos attempted to determine which one was more successful at shifting attitudes towards LE from unfavorable to favorable. Consequently, the type of primary data that was collected consisted of both quantitative and qualitative data to identify changes in the numbers of participants who harbored one view as well as the reasons for it.

\section{Participants and Data Collection}

Two surveys were conducted with six IB Theory of Knowledge (TOK) classes of around 85 students at an international school near London between the 25th of February and the 2nd of March 2021 over Zoom. One survey was completed before the videos and the second was completed immediately afterward. TOK is a class that encourages students to think critically about real-life situations, thus making LE relevant to the curriculum. Both surveys were constructed and completed by participants on Google Forms and organized and analyzed using Google Sheets.

\section{Methodological Approach}

The method for this study was split into three phases within a single class period (1 hour) in order to maintain replicability by preventing students from acquiring information about LE from sources other than those provided by the researcher. Discussion of material between phases was not permitted as students could have influenced, and been influenced by, their peers' views, which would have lessened the replicability of the method.

The first phase consisted of a five-section survey. The first section was simply an agreement to the terms outlined in a consent form, thus mitigating any ethical issues, such as privacy concerns, that may have arisen. The second section questioned the participants' attitudes towards developments in science and technology (which, as established by Dragojlivic, played a significant role in determining LE perceptions) by asking whether they supported all, some, or no scientific research. In order to understand fiction's influence on people's perception of LE, participants were then asked whether they knew any forms of media that represented characters with long lifespans.

The third section asked participants if they would want to live past the current maximum of 120 years. The fourth section used the same question, but specified that "living past 120 years would include maintaining health and vitality by not being as susceptible to the aging process." Participants were then asked to share what they believed to be positive and negative consequences of LE to encourage them to think deeper about their own perceptions before they were exposed to extrinsic information. 
The last section asked participants to tick all the factors they considered to be relevant in determining whether they held positive or negative beliefs about LE technologies. Such factors included representation of LE in fiction, ethical/social values, culture, concerns about feasibility, and personal desires.

In the second phase, participants were shown one of three video presentations created by the researcher. The presentations pertained to the three main aspects of the LE debate and all defined life extension to be "living past the current maximum of 120 years while maintaining health and vitality by not being as susceptible to the aging process". In the scientific presentation, the researcher discussed the mechanisms behind aging and detailed scientific breakthroughs that have extended the lives and minimized the effects of aging on various organisms (such as mice and humans) to demonstrate that LE is feasible due to the extensive research that is being done into its development.

For the ethics presentation, the researcher drew on the main ethical concerns cited by participants in previous studies: LE is unnatural, LE changes what it means to be human, LE is selfish, and LE goes against religious beliefs. Supporting and undermining evidence for those concerns was provided to ensure participants acquired a nuanced understanding of LE and its implications.

The social and personal presentation resembled the ethical video due to an overlap in concerns about unequal access to LE technologies. Other topics included overpopulation, concerns about the quality of life, and increased strain on existing socio-economic systems. Similarly, both advantages and disadvantages of the argument were discussed.

The third and final phase of the method used a survey consisting of three sections. In the first, participants were asked to specify which of the three presentations they watched. Next, participants were given multiple-choice questions to detail if and how their attitudes changed. In the third section, participants were asked to cite the reasons behind their attitudes towards LE, as instructed in the first phase, to compare the results and determine the effectiveness of the video presentations.

\section{Further Justification for Methodology}

Although no research has attempted to change attitudes towards LE itself, studies that have provided participants with information to change their attitudes towards other topics have had some success. For example, when chiropractic undergraduate students participated in a community health class lasting one semester, they exhibited more favorable attitudes towards public health concepts, such as collaboration between chiropractors and public health agencies, compared to before the course (Rose \& Ayad, 2008). Additionally, although Rose and Ayad's chiropractic study established that knowledge and attitudes are linked, it is a fairly loose connection since although favorable attitudes did increase, it was not to the extent that their knowledge did. This may suggest an element of unpredictability as to whether more information is effective in promoting favorable attitudes, which likely depend on additional factors such as personal opinions and values. Similarly, Lee et al found that nursing students who took a gerontology course (which involved lectures, clinical practice, and engagement in senior programs in the community) had much more favorable perceptions of older adults than those who did not take the course. However, since the effects of LE are very much hypothetical, it is impossible to arrange an equivalent educational experience for LE. Since all these studies focus on altering attitudes over the course of a semester, this study will also aim to determine whether a short presentation providing the most significant points and information would have the same effect on attitudes as a semester-long course.

Although educational courses seem to be effective in altering attitudes, knowledge alone may not affect attitudes to a, particularly significant extent. Harris et al (2010) found that although participants read an expert interview about obesity, which increased the participant's factual knowledge, their attitudes towards obese people stayed negative. However, although the videos shown to the participants in this study did heavily rely on factual information, especially the scientific aspect, other informative elements were also targeted such as ethicality, which may increase chances for a favorable attitude change. In fact, Harris et al's study findings contrasted with Zhu and Xie's findings which revealed that knowledge significantly contributed to positive attitude formation towards genetically modified 
(GM) foods. It was found that although an increase in general knowledge and "benefit knowledge" (as stated by Zhu and Xie) reduces misconceptions and unfamiliarity, "risk information" strengthens participant's trust in the information, which can shift participants' attitudes in a more favorable direction. "Benefit information" is less trusted than mixed or "risk information", thus indicating that providing participants with a balanced presentation of both sides of the argument is a promising approach to change attitudes from negative to positive. The current LE study provided participants with both favorable and unfavorable arguments towards LE, which should maximize the chances of a favorable shift in attitudes.

\section{Results}

When responses to participant's general perspective regarding developments in science and technologies were compared to whether they were interested in living past 120 years, $86 \%$ of those who supported all scientific and technological advancements were interested in LE; whereas only 75\% of those who supported some advancements were interested in LE. These findings corroborate Dragojlovic's ideas and illustrate that general attitudes towards science and technology do indeed play a role in determining a person's interest in LE.

\section{Interest in LE While Supporting All Research and Innovation}

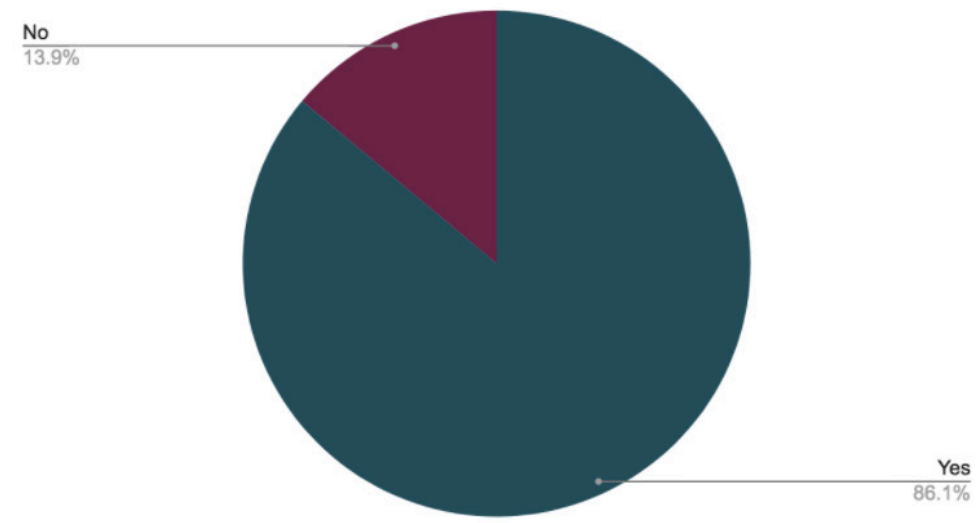

Interest In LE While Supporting Some Research and Innovation

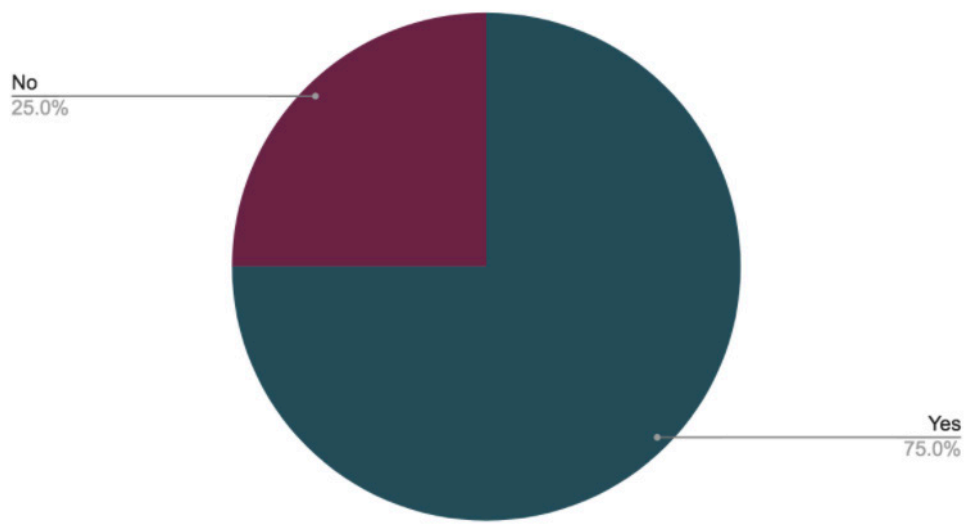


In regards to LE fiction, $86 \%$ of those who had not been exposed to it were interested in LE compared to $77 \%$ of those who had been. Additionally, those who were not interested in LE made up 23\% of those who had been exposed to LE fiction compared to only $14 \%$ of participants who had not seen any LE-related fiction. These findings suggest that the representation of extended life-spans in fiction may be significant in making the public less accepting of LE technologies and treatments.

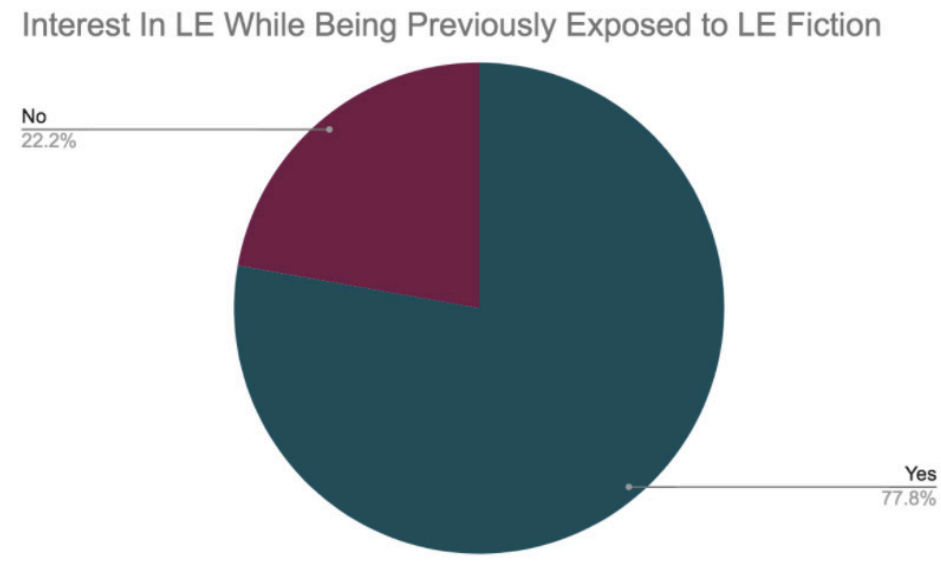

Interest In LE While Never Being Previously Exposed to LE Fiction

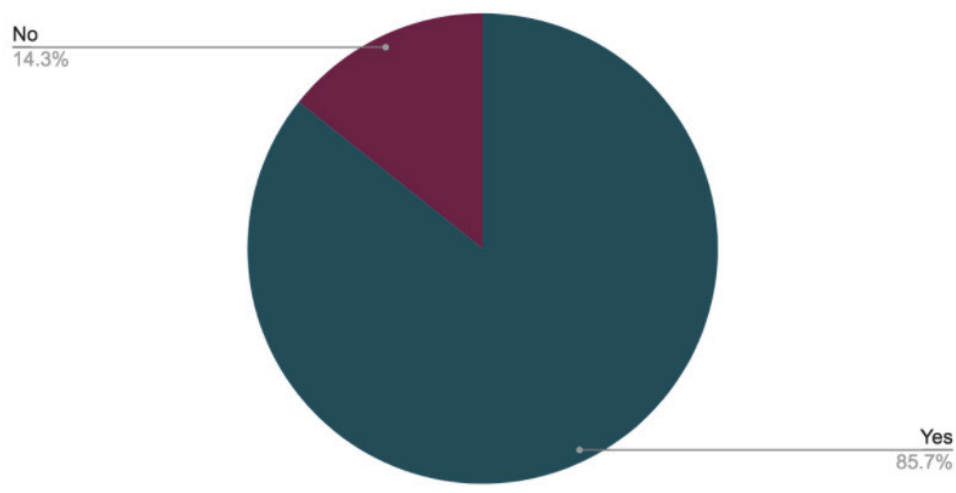

When asked whether they would be interested in living past 120 years, only $39 \%$ of participants said yes. However, after it was specified that they would live in health and vitality, that number increased drastically to $80 \%$, and only $20 \%$ of participants rejected it compared to $61 \%$ when health conditions were not specified. These results indicate that specification of the physical state people would live in when their lifespans are extended is vital in increasing favorable attitudes towards LE, which is consistent in the variation in findings of how many people wanted to live longer when health was and wasn't specified in Duncan's New York Times survey. 
"Would You Be Interested in Living past 120 Years?"

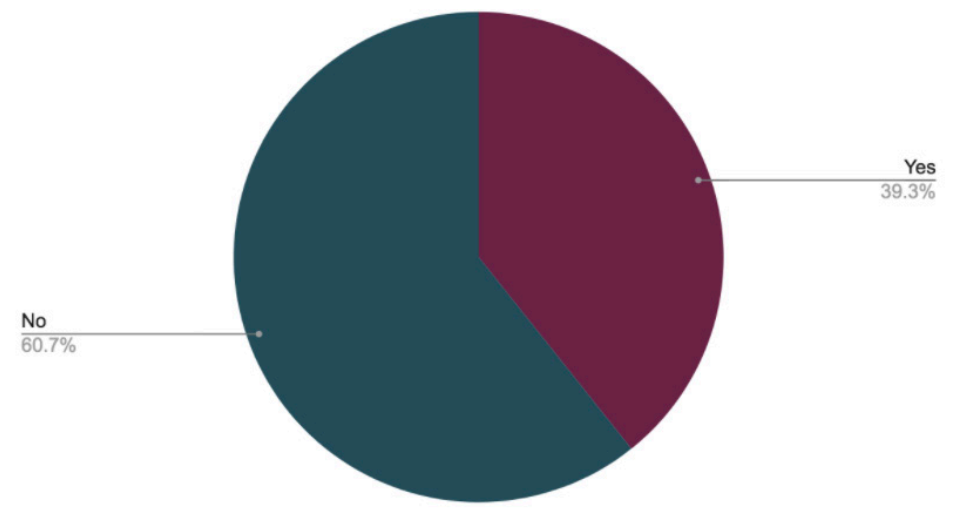

"Would You Be Interested in Living Past 120 Years While Maintaining Health and Vitality?"

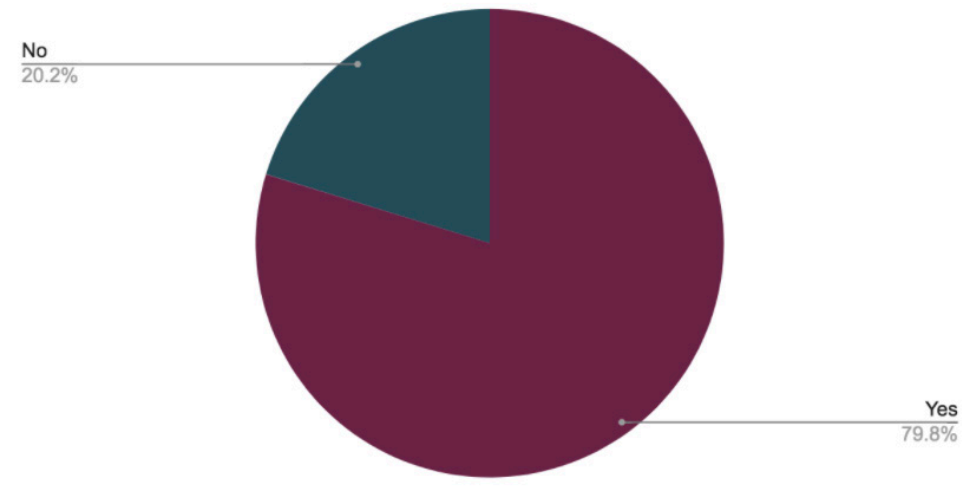

Interestingly enough, only $4.3 \%$ of responses cited prolonged health as a positive argument. Therefore, it can be concluded that although participants find physical state to be a significant factor in determining their interest in LE, it is not something that they would consider to be 'positive'. Instead, $28 \%$ of responses cited more time to be a major positive factor followed closely by the evolution of society and humanity, which constituted $22.6 \%$ of responses. Other arguments included loved ones (i.e them living longer and being able to spend more time with them: 18.3\%), witnessing societal and technological change (10.8\%), transgenerational interaction (i.e passing down knowledge and wisdom, and being able to interact with descendants: 9.7\%), and increased individual and collective knowledge (6.5\%). Evidently, participants roughly saw an equal amount of personal and social benefits to LE. 


\section{Positive Arguments}

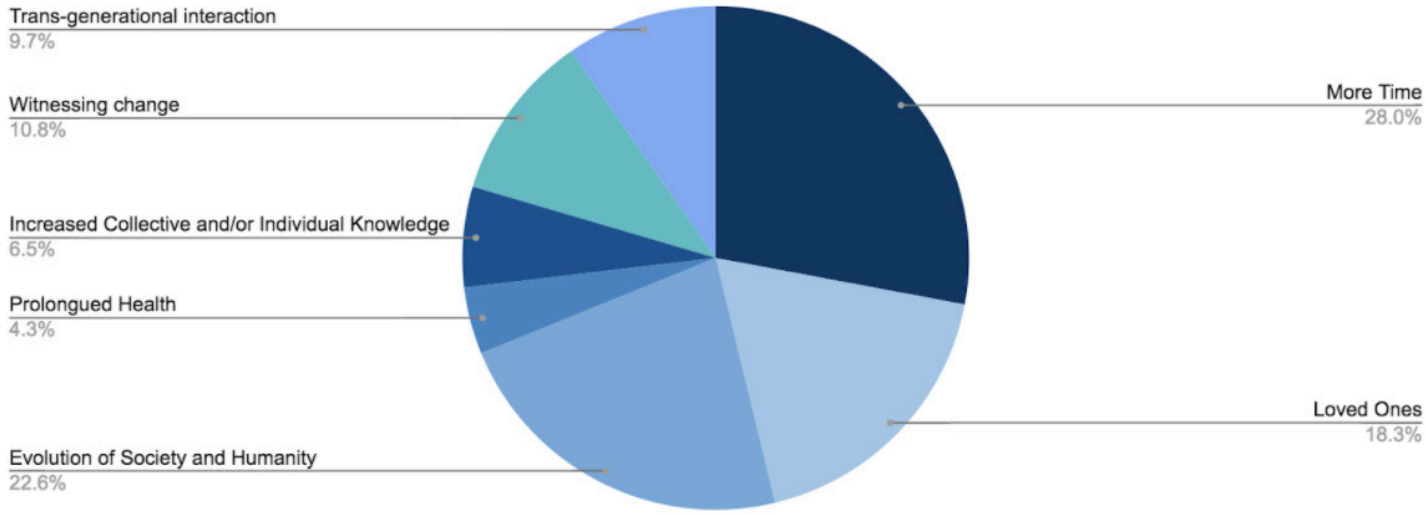

\begin{tabular}{|c|c|}
\hline Example Participant Response (Positive Arguments Towards LE) & $\begin{array}{l}\text { Category/catego- } \\
\text { ries }\end{array}$ \\
\hline $\begin{array}{l}\text { "In general, life is fun and good, so being able to live longer would be a positive thing for } \\
\text { a lot of people. Also, a lot more knowledge and experience is kept alive in the older people } \\
\text { who have lived through a number of timelines" }\end{array}$ & $\begin{array}{l}\text { More time } \\
\text { Increased individ- } \\
\text { ual/collective } \\
\text { knowledge }\end{array}$ \\
\hline $\begin{array}{l}\text { "You would have more time to explore the world and try anything that you wanted. For } \\
\text { example, you wouldn't have to pick just one or two areas to get a masters degree [and] you } \\
\text { could study and learn about as much as you wanted to. You could also experience every } \\
\text { culture if you wanted to. You would also get to see more time pass and therefore see the } \\
\text { different trends that come and go and you would get to experience them as a young person. } \\
\text { You would also get to enjoy being young more, rather than always worrying about your } \\
\text { future plans." }\end{array}$ & $\begin{array}{l}\text { Increased individ- } \\
\text { ual/collective } \\
\text { knowledge } \\
\text { More time } \\
\text { Witnessing } \\
\text { change }\end{array}$ \\
\hline $\begin{array}{l}\text { "People can live longer and experience life for a longer time, people who are beneficial to } \\
\text { society could live longer." }\end{array}$ & $\begin{array}{l}\text { More time } \\
\text { Evolution of soci- } \\
\text { ety and humanity }\end{array}$ \\
\hline $\begin{array}{l}\text { "You can spend more time with loved ones and family members such as grandparents and } \\
\text { great grandparents, people would have much more time to study and gain experience be- } \\
\text { fore going into roles such as teaching or government positions. People with more life ex- } \\
\text { perience would probably be much better at these roles and would have a positive impact } \\
\text { on society as a whole." }\end{array}$ & $\begin{array}{l}\text { Loved ones } \\
\text { More time } \\
\text { Increased individ- } \\
\text { ual/collective } \\
\text { knowledge } \\
\text { Evolution of soci- } \\
\text { ety and humanity }\end{array}$ \\
\hline $\begin{array}{l}\text { "On a personal level, people could have more time with loved ones, family and friends. } \\
\text { For society, if great minds did this, more innovations could be made before that person } \\
\text { died." }\end{array}$ & $\begin{array}{l}\text { More time } \\
\text { Loved ones } \\
\text { Evolution of soci- } \\
\text { ety and humanity }\end{array}$ \\
\hline
\end{tabular}




\begin{tabular}{|l|l|}
\hline $\begin{array}{l}\text { "People's average health would be better, and they will have the possibility to experience } \\
\text { and do more things." }\end{array}$ & $\begin{array}{l}\text { Prolonged health } \\
\text { More time }\end{array}$ \\
\hline $\begin{array}{l}\text { "One would gain more experience in life and can pass this valuable information onto the } \\
\text { next generation which can improve and advance society. New advancements in technology } \\
\text { regarding human life would be a big step in science and advancements. This would give } \\
\text { science and also society a new platform to advance further and improve general health and } \\
\text { conditions in the future." }\end{array}$ & $\begin{array}{l}\text { Increased indivion } \\
\text { uallective } \\
\text { knowledge }\end{array}$ \\
\hline "You'd get to meet all of the generations below you." & $\begin{array}{l}\text { Transgenerational } \\
\text { interaction }\end{array}$ \\
\hline
\end{tabular}

However, after being asked to provide arguments against LE, participants focused more on societal implications rather than personal ones. The majority of the responses $(55.6 \%)$ mentioned overpopulation as a concern. Other negative arguments included loved ones (i.e outliving family members: $15.3 \%$ ), abuse of power (13.9\%), social divide $(8.3 \%)$ and regression in societal development (due to an ageing population and lack of new ideas: 6.9\%). It is apparent that concerns about LE pertain mostly to the societal sphere rather than the personal.

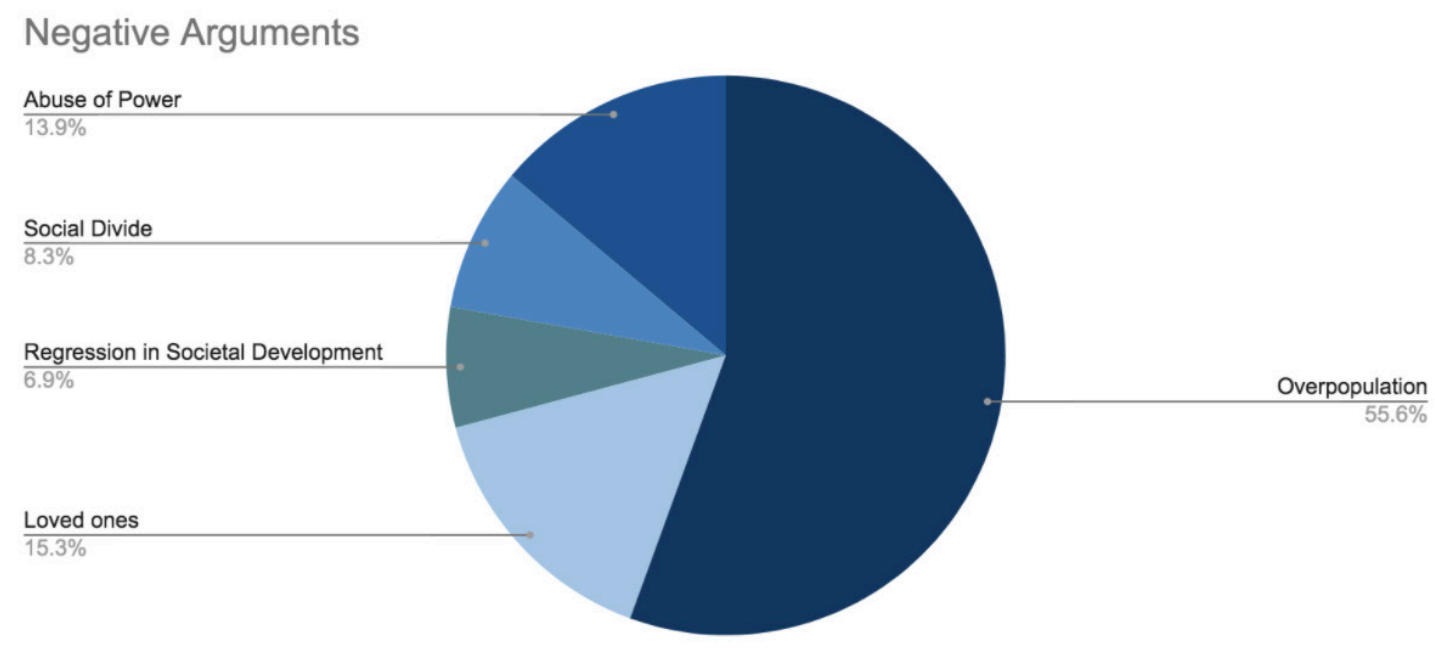

\begin{tabular}{|l|l|}
\hline Example Participant Response (Negative Arguments Towards LE) & $\begin{array}{l}\text { Category/cat- } \\
\text { egories }\end{array}$ \\
\hline $\begin{array}{l}\text { "The environment is already struggling greatly and adding to overpopulation would continue } \\
\text { to damage it. The Earth cannot sustain the number of humans alive now so it won't be able } \\
\text { to sustain more lives at once." }\end{array}$ & $\begin{array}{l}\text { Overpopula- } \\
\text { tion }\end{array}$ \\
\hline $\begin{array}{l}\text { "Society's development could possibly regress. Personal issues would also include you out- } \\
\text { living your loved ones and not being able to interact with them anymore." }\end{array}$ & $\begin{array}{l}\text { Regrion in } \\
\text { societal devel- } \\
\text { opment } \\
\text { Loved ones }\end{array}$ \\
\hline
\end{tabular}




\begin{tabular}{|c|c|}
\hline $\begin{array}{l}\text { "It would take a substantial toll on the world's resources and make it hard for younger people } \\
\text { to get jobs, earn enough money to survive, enough food, etc. Housing would become far more } \\
\text { expensive and the whole economy would be completely changed." }\end{array}$ & $\begin{array}{l}\text { Regression in } \\
\text { societal devel- } \\
\text { opment } \\
\text { Social divide }\end{array}$ \\
\hline $\begin{array}{l}\text { "It would (at least initially) not be offered to everyone, powerful people could stay in power } \\
\text { longer (even if they are too powerful or abuse their position). The world could not support so } \\
\text { many people not dying and the populations continued growth. There are many ethical con- } \\
\text { cerns with this, who would get an extended life? Would this just allow them to gain too much } \\
\text { power? Would they then abuse it? Can the world support that? should we mess with the nat- } \\
\text { ural order of what has worked for thousands of years?" }\end{array}$ & $\begin{array}{l}\text { Social divide } \\
\text { Abuse of } \\
\text { power }\end{array}$ \\
\hline $\begin{array}{l}\text { "There would be overpopulation issues for sure, though I suppose having more smart people } \\
\text { around for longer might help us solve that. There would also be government problems, like } \\
\text { with Putin always adding eight more years onto his term as president or whatever. It would } \\
\text { also probably screw up the economy, though I can't think how exactly." }\end{array}$ & $\begin{array}{l}\text { Overpopula- } \\
\text { tion } \\
\text { Abuse of } \\
\text { power } \\
\text { Regression in } \\
\text { societal devel- } \\
\text { opment }\end{array}$ \\
\hline $\begin{array}{l}\text { "I think that there would be a lot of discourse on how to extend everyone's lives. There will } \\
\text { be conflict between the different classes because this sort of technology would be very ex- } \\
\text { pensive, so those of the lower classes probably wouldn't be able to afford it, causing more } \\
\text { inequality than there already is. Additionally, if you were to use the life extension technolo- } \\
\text { gies and then the people you love don't, then you'll live without them for a long time, which } \\
\text { I think is something that no one wants." }\end{array}$ & $\begin{array}{l}\text { Social divide } \\
\text { Loved ones }\end{array}$ \\
\hline $\begin{array}{l}\text { "Putting effort towards researching and implementing life extension technologies for people } \\
\text { in the developed world, where people already have long lives, is not the best option. In many } \\
\text { poorer countries, people have lifespans as low as } 55 \text { years; we should be putting our efforts } \\
\text { into implementing our already existing technology to raise the lifespans of the people with } \\
\text { the shortest lives rather than those with the longest lives." }\end{array}$ & Social divide \\
\hline $\begin{array}{l}\text { Contribution to overpopulation, average age of population increases, workers will pay more } \\
\text { taxes towards elderly care, retirement age will increase }\end{array}$ & $\begin{array}{l}\text { Overpopula- } \\
\text { tion } \\
\text { Regression in } \\
\text { societal devel- } \\
\text { opment }\end{array}$ \\
\hline
\end{tabular}

After being shown the video presentations, there was only a menial change in the demographic of factors determining general participant attitudes towards LE. Curiosity/concern about the future came in first $(65.5 \%$ before the videos and $61 \%$ after $)$; ethical/social values came in second (64.3\% before and $59.7 \%$ after); personal desires came in third (41.7\% before and 33.8\% after) and outlook towards science and technology came in fourth $(33.3 \%$ before and $24.7 \%$ after). After the video was shown, the order was shifted slightly. The most notable changes included concerns about feasibility increasing from $17.9 \%$ to $24.7 \%$ and culture decreasing from $23.8 \%$ to $14.3 \%$. It should also be noted that religion was cited the least, regardless of timing, and lowered from $15.5 \%$ to $13 \%$. Although there was a general decrease in percentages of people citing various concerns, the changes were not significant enough to be 
correlated with the participants' exposure to new information about LE and can be attributed to the decrease in participants answering the second survey (77 compared to 84 ).

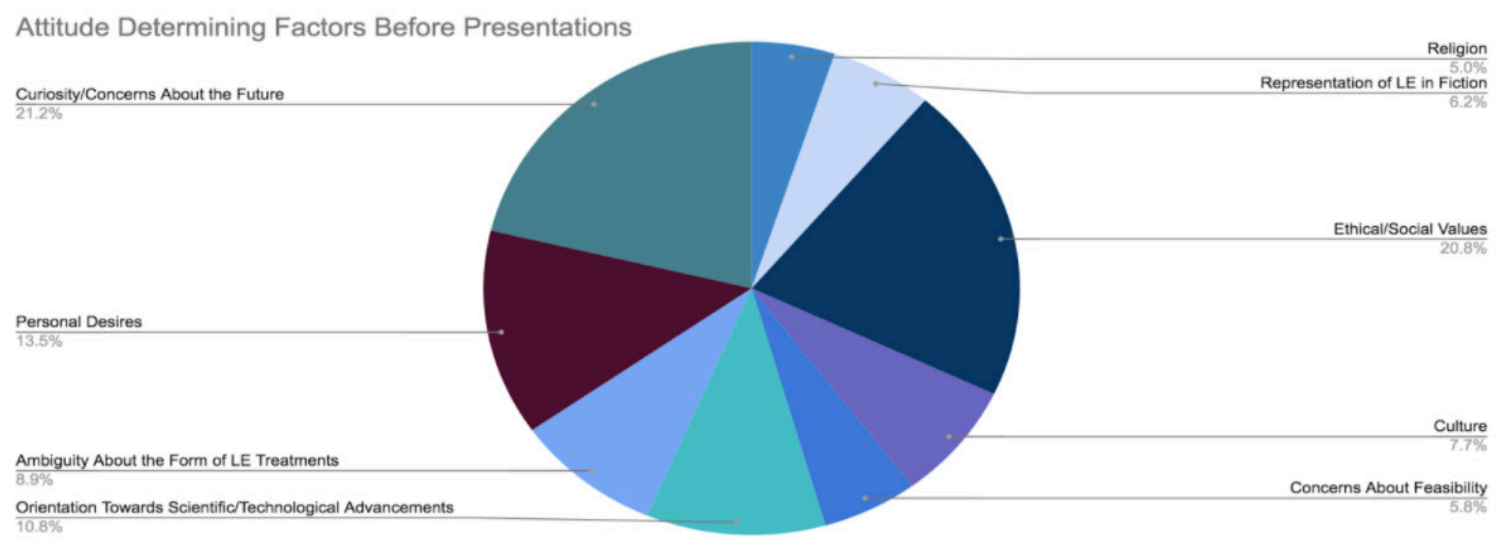

Attitude Determining Factors After Presentations - General

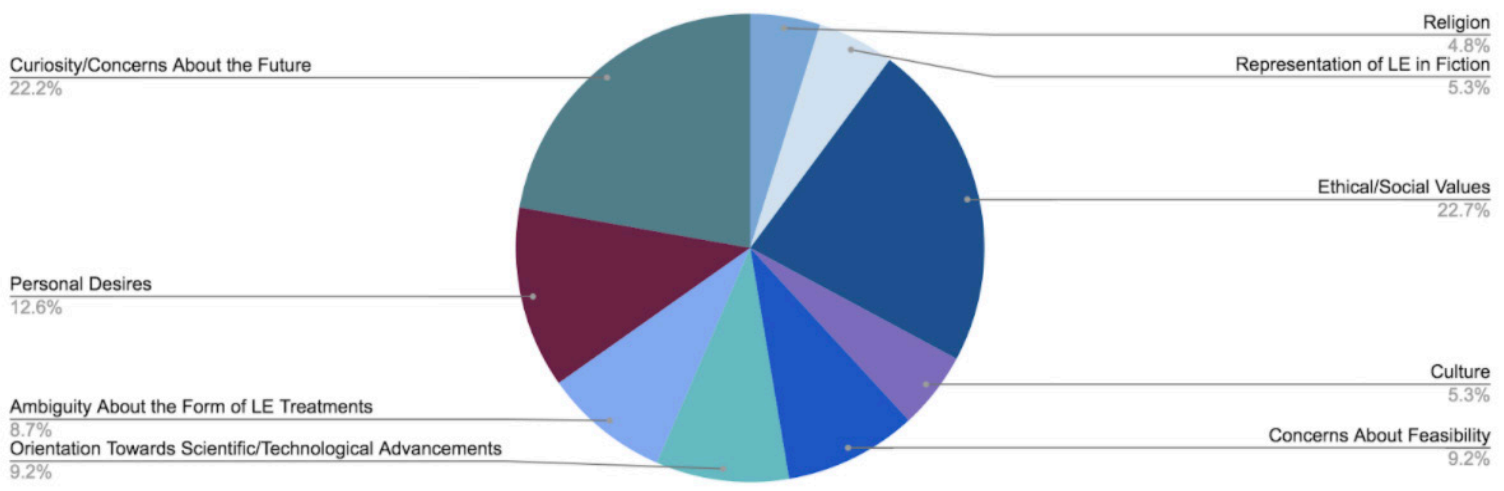

Attitude Determining Factors After Scientific Presentation

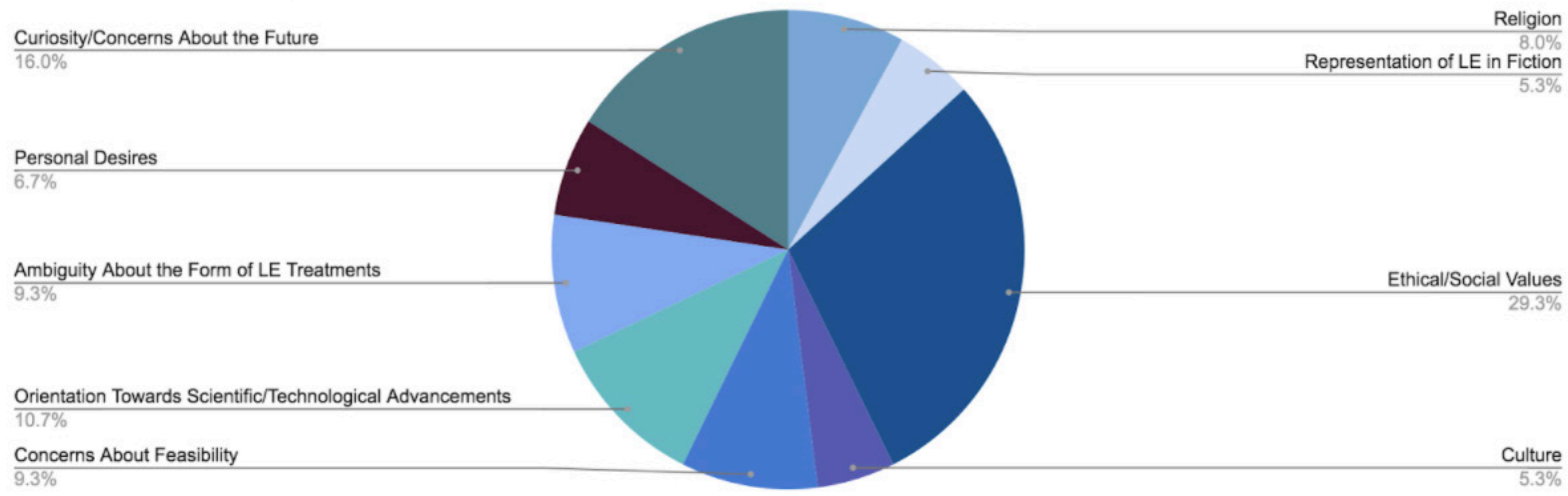


Attitude Determining Factors After Ethical Presentation

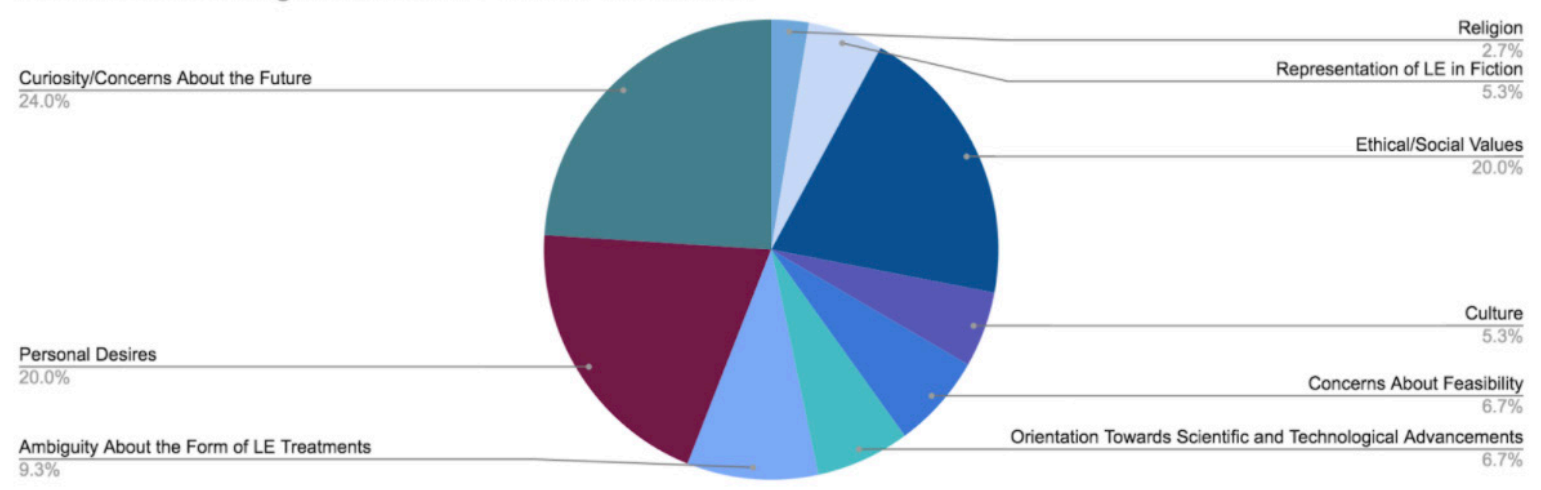

Attitude Determining Factors After Social Presentation

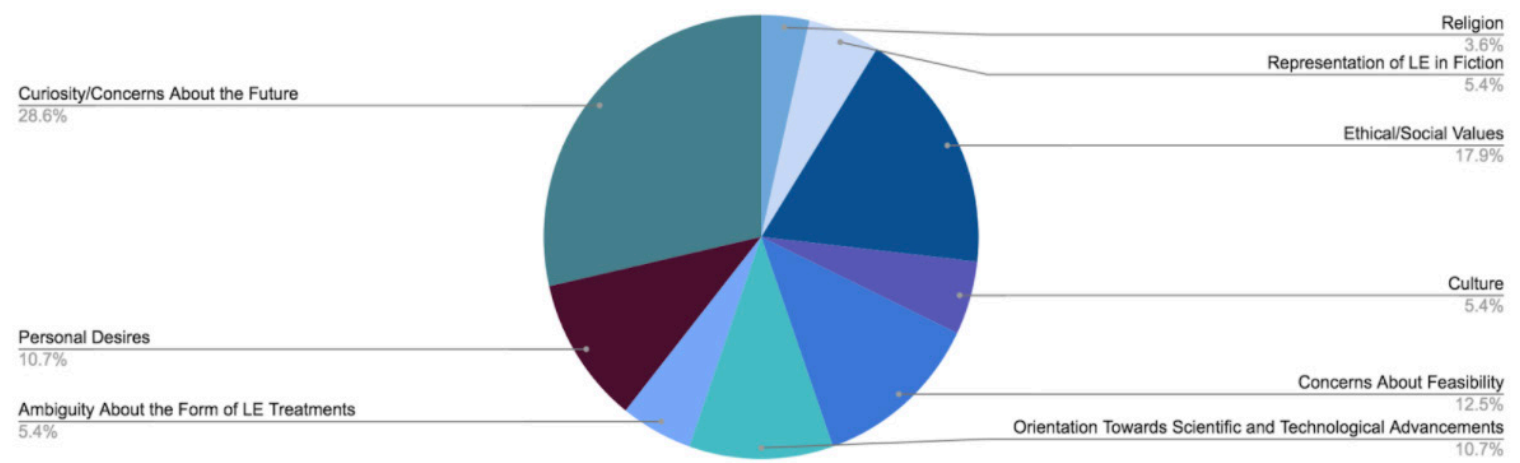

In general, separate video presentations of the aspects of the LE debate were largely ineffective in changing attitudes since $79.2 \%$ of participants did not experience a change and only $20.8 \%$ did. Despite participants citing primarily social and personal aspects in their arguments against LE, the social/personal presentation was least effective in changing attitudes with only $15 \%$ of participants reporting a change. While $21.4 \%$ of participants changed their attitudes in response to the ethical video, the most effective video, surprisingly, was the scientific one which resulted in $24 \%$ of participants changing attitudes. Even though the ethical and social/personal video addressed the concerns cited by participants in previous studies, it was not as effective as the scientific video in changing attitudes in favor of LE. 


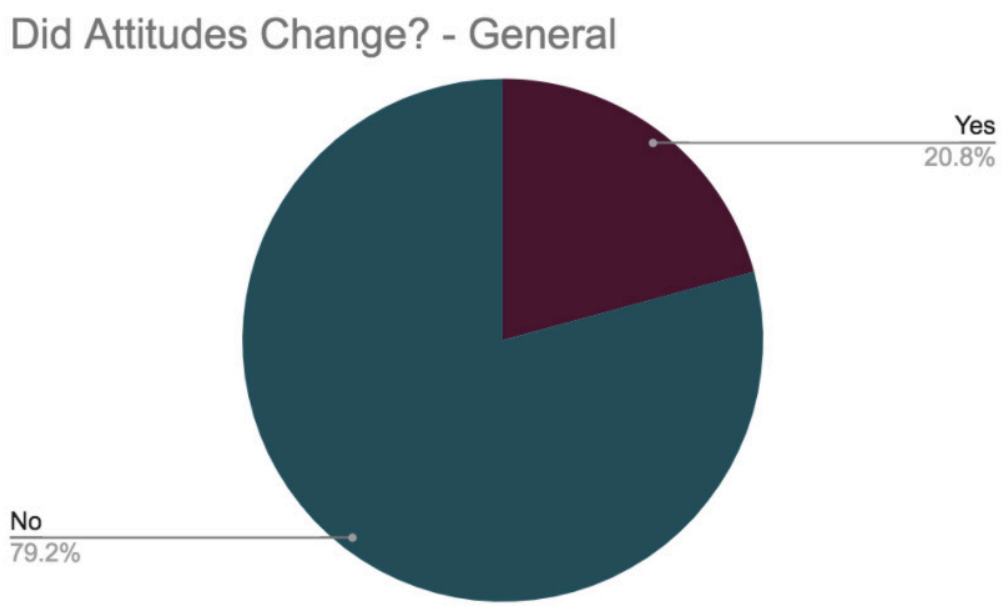

\section{Did Attitudes Change? - Ethical}

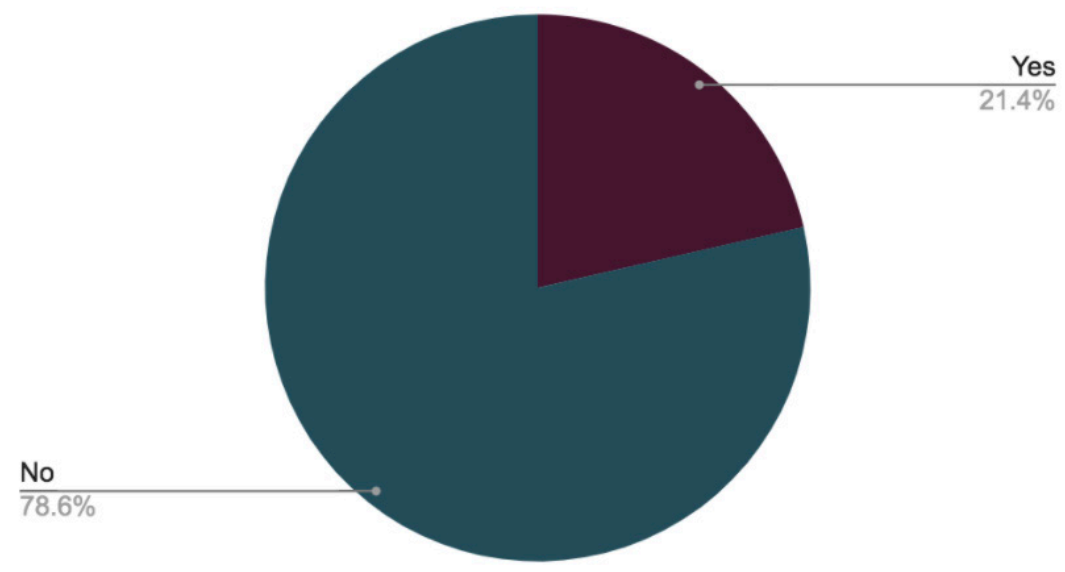

Did Attitudes Change? - Scientific

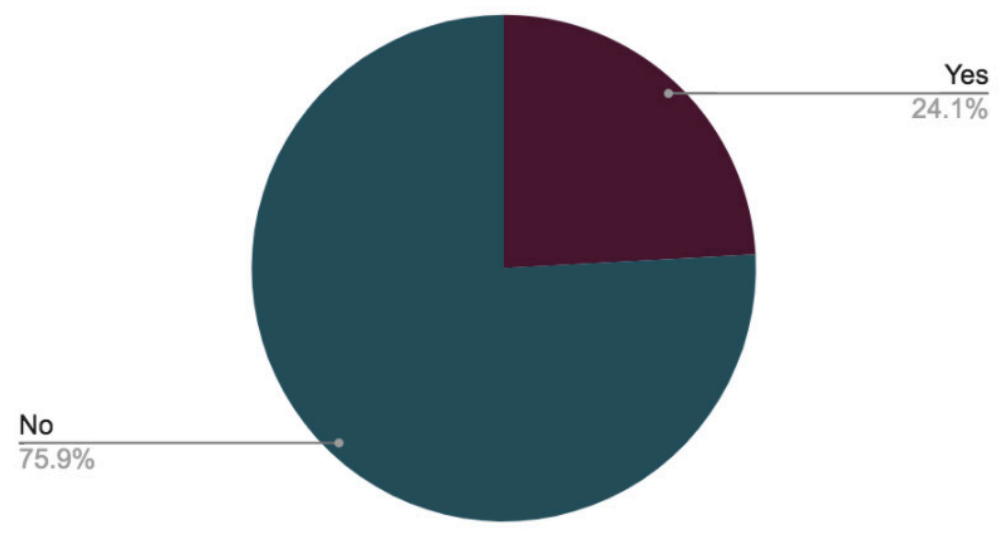




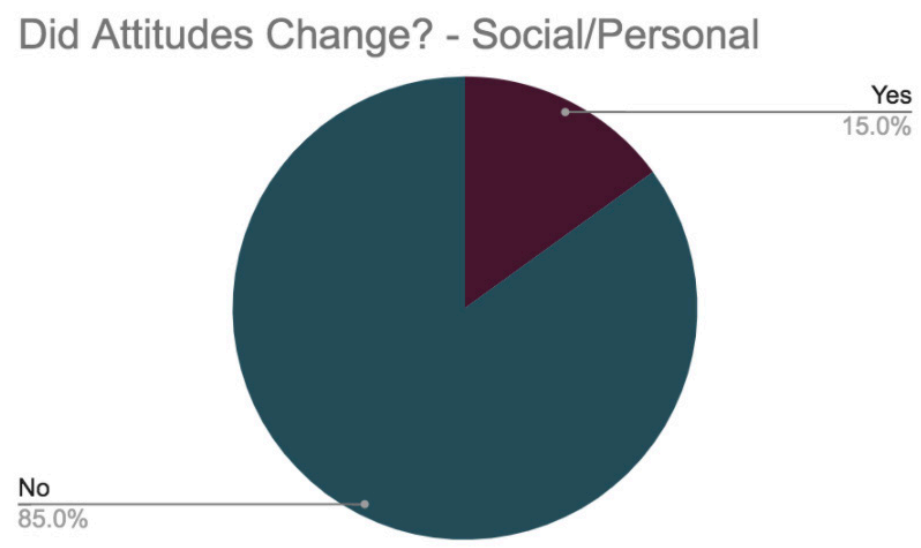

Although the majority (80\%) of participants said they would be interested in living past 120 years in health, the majority (40.3\%) of participants stated their attitudes stayed negative after watching the videos and 35\% said their attitudes stayed positive. 9.1\% reported that their attitudes changed from negative to positive, $6.5 \%$ reported they became even more positive, $5.2 \%$ stated their attitudes went from positive to negative, and $3.9 \%$ said their attitudes became even more negative.

The ethical video resulted in $10.7 \%$ of participants changing their attitudes from positive to negative and only $3.6 \%$ said that their attitudes changed from negative to positive and the same (3.6\%) for positive to more positive. The scientific video resulted in the most favorable change where $17.2 \%$ of participants changed their attitudes from negative to positive and $13.8 \%$ said their attitudes changed from positive to even more positive, while a much smaller percentage reported a negative change $(6.9 \%$ changed from negative to more negative and $3.4 \%$ changed from positive to negative). The social/personal video was the least effective in changing attitudes since only $5 \%$ reported their attitudes changing from negative to positive and the same $(5 \%)$ from negative to more negative.

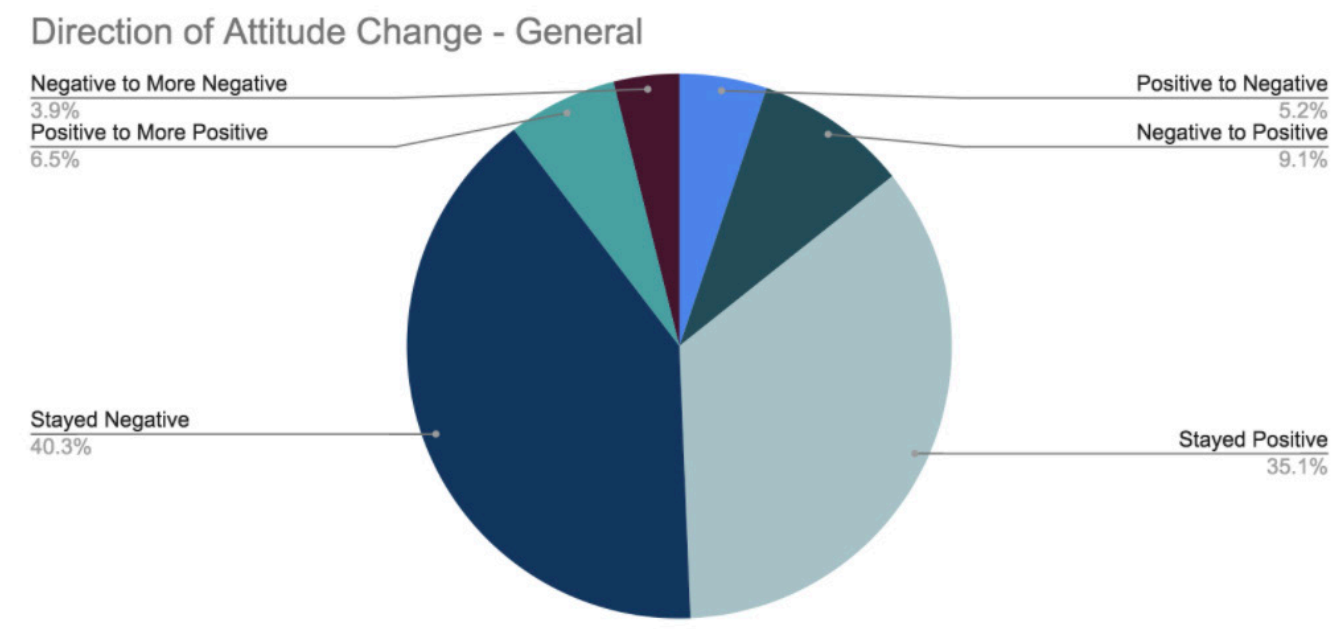


Direction of Attitude Change - Ethical

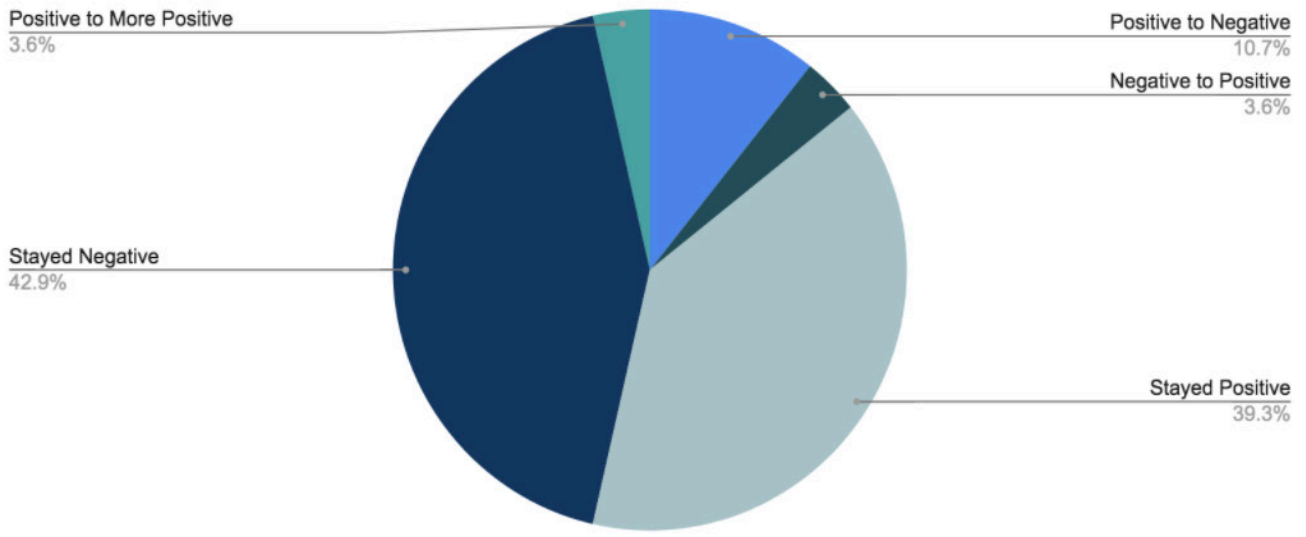

Direction of Attitude Change - Scientific

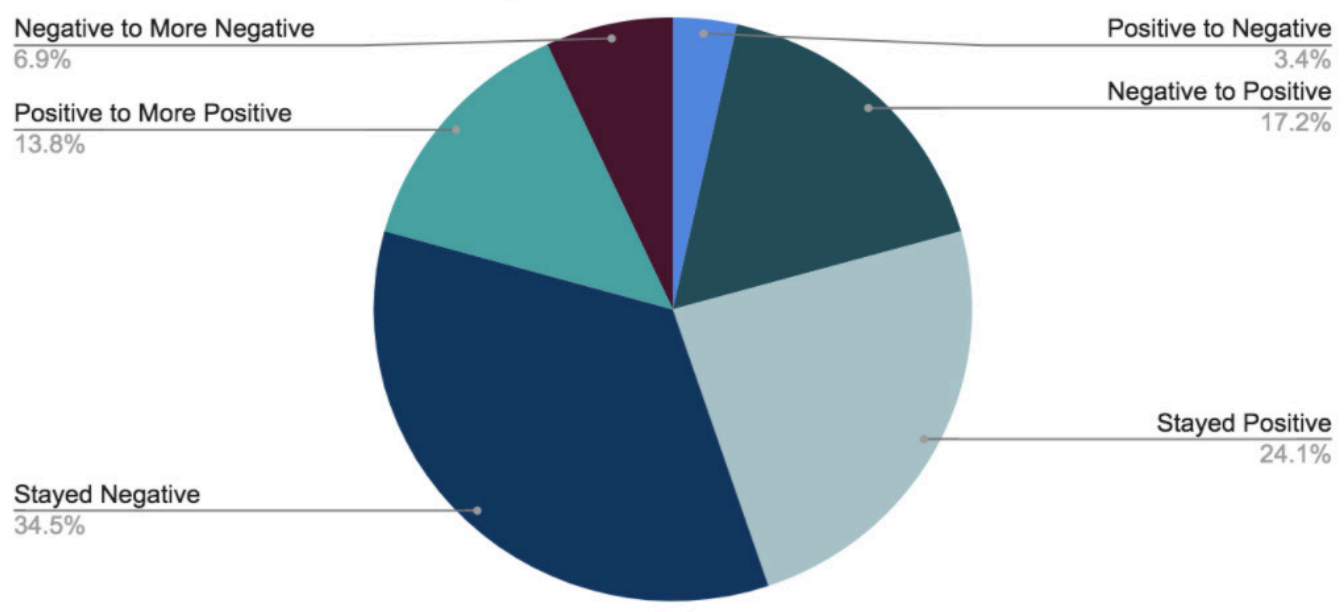

Direction of Attitude Change - Social/Personal

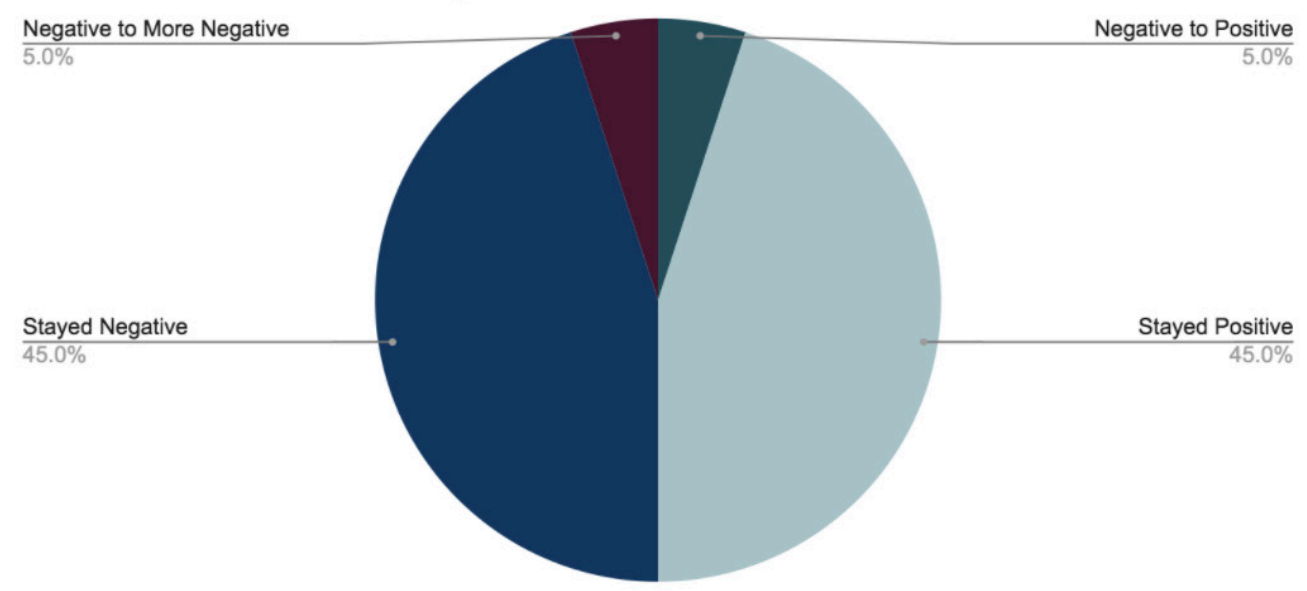




\section{Conclusion}

In this project, various attitude-shaping factors were investigated in order to determine if individuals are interested in living past 120 years and whether they hold a positive or negative view of LE. Additionally, it was also explored whether a fifteen-minute video presentation delineating one of three spheres of the LE debate is effective in not only changing a person's attitude towards LE but also changing it in a favorable direction. The fact that various studies measuring the public's perception of LE exhibit different findings gives exigency to this study, which aimed to clarify contradictions and discrepancies among other studies, particularly the conflicting results in Dragojlovic and Calnan et al's studies.

Although this study was unsuccessful in changing attitudes by educating participants on the controversy surrounding LE, it was able to isolate which type of information is most likely to promote favorable attitudes as well as determine elements that potentially shape people's perception of LE. It was determined that a more factual, scientific approach is the most effective way in representing LE more favorably rather than a more polarizing discussion of ethics and implications.

In order to increase favorable public attitudes, researchers and communicators should aim to promote favorable perceptions of science in general (since evidence suggests they are linked), as well as either increasing favorable representations of LE in fiction or debunking false perceptions of LE perpetrated by it. Additionally, communicators could place a greater emphasis on positive elements of LE as identified by the participants such as having more time, contributing and witnessing the development of society and humanity, and spending more time with loved ones. It is also important to allay significant concerns voiced by the public, particularly overpopulation because, according to Zhu and Xie's findings, that should also aid in positive attitude formation. Although it is important to address various concerns about the implications of LE, that does not seem to be effective due to only a minor change for the better in attitudes from the ethical and the social and personal presentations. However, this may be due to the fact that supporting evidence for those concerns was provided. Further research could follow the same framework as this study but only provide only undermining and allaying information for concerns. In fact, communicators and researchers should aim to reassure the public that LE would be beneficial to society in the future.

Despite most participants exhibiting interest in LE if health is maintained, the majority stated that their attitudes were negative before becoming more informed as well as after. This reflects Partridge et al's findings in which participants indicated that what they personally would like is not consistent with what contributes to the greater benefit of society. Thus, it is necessary to assure the public that their personal desires are not detrimental. Of course, since many people do not know very much about LE, the only basis for their beliefs and attitudes is fiction and popular media which demonizes LE and its pursuit as concluded by Underwood in her research.

\section{Discussion and Limitations}

A reason why this study's method to change attitudes was ineffective could be because participants didn't get the 'full picture' of LE. It would be interesting to assess whether having a group watch all three videos and compare the results to groups that only watched one video. This could potentially establish that in order for participants' attitudes to change in a more favorable direction, they would need to be informed about all perspectives (scientific, personal and social, and ethical) of the LE debate instead of only one.

Additionally, alternate methods of increasing knowledge and awareness of LE could be explored. A possible approach could include one similar to Rye and Meaney's study in which a panel of relevant authorities on LE discuss their research and its implications with participants (such as those from organizations dedicated to extending human lifespan). Such method could ensure participant engagement much more effectively since a limitation of this study was that there was no way for the researcher to monitor engagement due to the presentation being pre-recorded. A lack of sufficient engagement may have interfered with the extent to which participant attitudes changed thus making 
the results less valid. A more intimate interaction in which discussion is encouraged could spark participant interest and engagement in a manner that a pre-recorded presentation delivered over zoom simply could not.

Unfortunately, because of the way the raw data was formatted, a comparison between results in the first and second survey was impossible. A trans-survey analysis could have further explored the disjunction between participants' interest in LE and their unfavorable attitude towards it. This could have been done by comparing interest in LE to whether participants' attitudes remained negative, or positive, or if they had changed. Further research using a similar three-phase framework could allow for greater relation between the two surveys.

\section{Acknowledgments}

I would like to express my gratitude to Dr. Mair Underwood who helped provide invaluable insight into my topic and helped me shape and direct my research. I would also like to thank Frances Bidwell for her continued support throughout my research process.

\section{References}

Alvarez, A., Mendoza, L., \& Danielson, P. (2015). Mixed views about radical life extension. Etikk I Praksis Nordic Journal of Applied Ethics, 9(1). doi:10.5324/eip.v9i1.1829

Arber, S., Vandrevala, T., Daly, T., \& Hampson, S. (2008). Understanding gender differences in older people's attitudes towards life-prolonging medical technologies. Journal of Aging Studies, 22(4), 366-375.

doi:10.1016/j.jaging.2008.05.009

Burials. Fieldwork Dates: 7th - 8th November 2018. Conducted by YouGov. On behalf of YouGov Omnibus. Calnan, M., Montaner, D., \& Horne, R. (2005). How acceptable are innovative health-care technologies? A survey of public beliefs and attitudes in England and Wales. Social Science \& Medicine, 60(9), 19371948. doi:10.1016/j.socscimed.2004.08.058

Cicirelli, V. G. (2011). Elders' attitudes toward extending the healthy life span. Journal of Aging Studies, 25(2), 8493. doi:10.1016/j.jaging.2010.08.011Donner, Y., Fortney, K., Calimport, S. R., Pfleger, K., Shah, M., \& BettsLaCroix, J. (2016). Great desire for extended life and Health amongst the American public. Frontiers in Genetics, 6. doi:10.3389/fgene.2015.00353

Dragojlovic, N. (2013). Canadians' support for radical life extension resulting fromadvances in regenerative medicine. Journal of Aging Studies, 27(2), 151-158. doi:10.1016/j.jaging.2012.12.008

Duncan, D. (2012, August 25). How long do you want to live? Retrieved April 26, 2021, from https://www.nytimes.com/2012/08/26/sunday-review/how-long-do-you-want-to-live.html

Fahy, G. M., West, M. D., Coles, L. S., \& Harris, S. B. (2010). The future of aging pathways to human life extension. New York: Springer.

Harris, M. B., Walters, L. C., \& Waschull, S. (1991). Altering attitudes and knowledge about obesity. The Journal of Social Psychology, 131(6), 881-884. doi:10.1080/00224545.1991.9924675

Juengst, E. T. (2003). AGING: Enhanced: Antiaging research and the need for public dialogue. Science, 299(5611), 1323-1323. doi:10.1126/science.1083135

Lang, F. R., Baltes, P. B., \& Wagner, G. G. (2007). Desired lifetime and End-of-Life Desires Across adulthood from 20 to 90: A dual-source information model. The Journals of Gerontology: Series B, 62(5). doi:10.1093/geronb/62.5.p268

Lee, Y., Shin, S., \& Greiner, P. A. (2015). Can education change attitudes toward aging? A quasi-experimental design with a comparison group. Journal of Nursing Education and Practice, 5(9). doi:10.5430/jnep.v5n9p90 
Living to 120 and Beyond: Americans"' views on aging, medical advances and radical life extension. (2020, May 30). Retrieved April 26, 2021, from https://www.pewforum.org/2013/08/06/living-to-120-and-beyond-americansviews-on-aging-medical-advances-and-radical-life-extension/

Moody, H. R. (winter 2001/2002). Who's afraid of life extension? Generations, 25(4), 33-37.

Partridge, B., \& Hall, W. (2007). The search for Methuselah. Should we endeavour to increase the maximum human lifespan? EMBO Reports, 8(10), 888-891. doi:10.1038/sj.embor.7401069

Partridge, B., Lucke, J., Bartlett, H., \& Hall, W. (2009). Ethical, social, and personal implications of extended human Lifespan identified by members of the public. Rejuvenation Research, 12(5), 351-357.

doi:10.1089/rej.2009.0907

Partridge, B., Lucke, J., Bartlett, H., \& Hall, W. (2011). Public attitudes towards human life extension by intervening in ageing. Journal of Aging Studies, 25(2), 73-83. doi:10.1016/j.jaging.2010.08.012

Partridge, B., Underwood, M., Lucke, J., Bartlett, H., \& Hall, W. (2009). Ethical concerns in the community about technologies to extend human life span. The American Journal of Bioethics, 9(12), 68-76.

doi:10.1080/15265160903318368

Rose, K. A., \& Ayad, S. (2008). Factors associated with changes in knowledge and attitude towards public health concepts among chiropractic college students enrolled in a community health class. Journal of Chiropractic Education, 22(2), 127-137. doi:10.7899/1042-5055-22.2.127

Shepherd, R., Barnett, J., Cooper, H., Coyle, A., Moran-Ellis, J., Senior, V., \& Walton,C. (2007). Towards an understanding of British public attitudes concerning human cloning. Social Science \& Medicine, 65(2), 377392. doi:10.1016/j.socscimed.2007.03.018

Shepherd, R., Barnett, J., Cooper, H., Coyle, A., Moran-Ellis, J., Senior, V., \& Walton, C. (2007). Towards an understanding of British public attitudes concerning human cloning. Social Science \& Medicine, 65(2), 377392. doi:10.1016/j.socscimed.2007.03.018

Underwood, M. (2014). What reassurances do the community need regarding life extension? Evidence from studies of community attitudes and an analysis of film portrayals. Rejuvenation Research, 17(2), 105-115.

doi:10.1089/rej.2013.1479

Wareham, C. S. (2020). Genome editing for longer lives: The problem of loneliness. Journal of Bioethical Inquiry, 17(2), 309-314. doi:10.1007/s11673-020-09967-w

Zhu, X., \& Xie, X. (2015). Effects of knowledge on attitude formation and change toward genetically modified foods. Risk Analysis, 35(5), 790-810. doi:10.1111/risa.12319 